\title{
Bud rot disease of coconut in relation to endemic spots in Kerala state, India
}

\author{
Rohini Iyer ${ }^{1}$ and A.R. Rasmi ${ }^{1}$
}

\begin{abstract}
In India bud rot is quite common on the West and East Coast tracts. A random survey on bud rot disease of coconut, caused by Phytophthora palmivora But.l, carried out in Kasaragod, Kannur and Calicut districts of Kerala revealed that, there is correlation between the disease incidence and the location of the palms. The disease incidence was high in the hilly tracts when compared to that of the plains. Studies on the survival of $P$. palmivora propagules in nature revealed that the pathogen survives in the crown, soil and roots of healthy and diseased palms. However, the percentage of survival was high in the endemic areas-Mandapam (Kasaragod District), Josegiri (Kannur Dist.) and Kuttiadi (Kozhikode Dist.), both in the case of diseased and healthy palms compared to that of areas with lesser disease incidence. The temperature and humidity in the coconut growing tracts of hilly areas of Kasaragod, Kannur and Kozhikode districts are suitable for the survival of the pathogen in the crown during almost all months, resulting in the high frequency of disease incidence during monsoon season and continued infection up to January. Examination of the rain water collected from bud rot affected coconut gardens also indicated that the pathogen surviving in the crown debris can act as a source of inoculum, which spreads to the neighboring palms through rain splashes. Based on the weather data it is possible to predict the bud rot incidence well in advance.
\end{abstract}

Key words: Bud rot disease, Phytophthora palmivora But.l, epidemiology, forecasting model, Kerala, India.

${ }^{1 /}$ Division of Crop Protection, Central Plantation Crops Research Institute, Kasaragod - 671 124, Kerala, India. 


\section{Introduction}

Coconut palm, in spite of its hardy nature is affected by a number of diseases, some of which not only reduce the yield but also kill the palms. Root (wilt) disease, bud rot, basal stem rot and stem bleeding diseases are the major coconut diseases causing heavy losses in India. The first report of bud rot incidence on coconut was from Grand Cayman, an island of British West Indies just south of Cuba in 1834 (Tucker, 1926). Butler (1906) reported bud rot disease of coconut from India. In India, bud rot is quite common on the West and East Coast tracts (Menon and Pandalai, 1958). Radha and Joseph (1974) reported a disease incidence of 0.12 to $6.5 \%$ in Kerala and 35 to 40 per cent was observed in certain gardens having large number of palms. Heavy incidence of bud rot disease has been reported from Kuttiadi (Kozhikode Dt.), in Kerala state leading to the destruction of thousands of coconut palms (Anonymous, 1996).

\section{Materials and methods}

\section{Survey}

A random survey was conducted in different localities of Kasaragod, Kannur, and Kozhikode districts of Kerala. During the survey, altitude, topography, and the extent of bud rot incidence in each coconut garden was recorded.

\section{Epidemiological studies on bud rot disease}

\section{Survival of pathogen in diseased gardens}

\section{a) In crown}

To study the survival of the pathogen in the crown of coconut palms, organic matter (debris) was collected from the axils of diseased and healthy palms. The plots studied were located in CPCRI Kasaragod, CPCRI Kidu farm (Dakshina Kannada Dist.), Mandapm (Kasaragod Dist.), Josegiri (Kannur Dist.), Udayagiri (Kannur Dist.) and Kuttiadi (Kozhikode Dist.). These samples were moistened with sterile distilled water and isolation was carried out by baiting using 2 month old Chowghat Orange Dwarf (COD) nuts. Percentage survival was calculated based on the frequency of positive isolations using the formula,

Number of samples with positive isolation x 100

Total number of samples observed

b) In roots

Coconut roots collected from diseased and healthy palms of bud rot affected gardens were thoroughly washed in running water. Roots were cut into small pieces with sterile scalpel and were inoculated in $\mathrm{P}_{10} \mathrm{ARP}$ medium for the isolation of Phytophthora.

c) In soil

To study the survival of the coconut Phytophthora in soil, the soil samples were collected from the diseased and healthy palms from bud rot affected coconut gardens and the isolations were carried out by baiting with immature nuts (two month old) and young spear leaf discs.

\section{Trapping of Phytophthora propagules from rain water}

For collecting rain water, plastic trays were fitted to bamboo poles at 15 and $35 \mathrm{~cm}$ above the ground and also at the base of the crown (Thevenin et al., 1992). Rain water samples collected in the trays were transferred to the laboratory in polythene bags for trapping, using COD (2 month old) nuts and percentage of isolation was calculated using the earlier formula.

\section{Survival of Phytophthora in slugs excreta}

Slugs (Mariaella dussumieri) were found to survive in the axil of the leaves. They were collected from crown debris of both diseased and healthy palms and were kept in moist boxes lined with wet filter paper and the excreta were collected and were made in to paste with sterile distilled water. The presence of Phytophthora inoculum was tested by microscopic observation and by wound inoculation in young spear leaf of coconut. 
Artificial feeding was done to study the survival and viability of the Phytophthora propagules in slugs' feces. Fresh smears of feces were observed under the microscope to study the perenating structures. To test the viability of sporangia, the feces were treated with 'Petris' solution and examined microscopically for zoospore release. The viability was also tested by inoculating the smears of feces on wounded spear leaf pieces.

\section{Relationship between bud rot incidence and macro and micro climate}

To study the relationship between the bud rot incidence in hilly tracts and plains, and the effect of macro and micro climates on disease incidence, three plots were identified, two in hilly (Josegiri (Kannur Dt.), Mandapam (Kasaragod Dt.)) and one in the plain (Bowkanam (Kasaragod Dt.)). The macro and micro climate factors and bud rot incidence was recorded for two years in these three plots.

\section{Results and discussion}

\section{Survey}

Survey on bud rot incidence in Kasaragod, Kannur, Kozhikode, Thrissur, Malappuram, Palakkad, Ernakulam and Wynad districts of Kerala revealed that there was a significant variation in bud rot incidence. Bud rot incidence was high in the northern districts viz., Kasaragod, Kannur, Kozhikode and Wynad districts as compared to other districts surveyed (Table-1). Observation recorded on the bud rot incidence in the hilly tracts and plain areas of the Kasaragod, Kannur and Kozhikode districts revealed that, the proportion of the diseased palms was high in the hilly tracts (300- $1350 \mathrm{M}$ above MSL) compared to that of the plains (150-300 M above MSL). Table-2 shows the proportion of diseased palms in hilly and plain tracts of Kasaragod, Kannur and Kozhikode districts. Bud rot of coconut was found to occur during the monsoon season when there is high humidity and low temperature in the atmosphere. However, in the hilly areas of Kasaragod, Kannur and Kozhikode districts it was noted that the disease incidence continued up to the month of January. In the plains, disease incidence was recorded only up to September.

In the northern districts of Kerala, the monsoon has a unimodal distribution starting from June and ending in October- November and most of the rain is received from the South West monsoon only. Where as in the central districts rainfall distribution is bimodal in nature and the rainy period is extended to both South West and North - East monsoon. From this it is evident that very high relative humidity prevails during the South - West monsoon in the plantations of northern districts. Since rainfall aggravates the infection, young palms in the low lying and moist conditions are more susceptible (Thevenin et al., 1992; Brahmana et al., 1992; Mangindaan et al., 1992; Pohe, 1992; Steer, 1992). The cooler post-monsoon weather also favours the formation of dew for extended periods and this conducive factor favours the development of fresh disease incidence in the hilly tracts compared to that in the plains.

\section{Epidemiological studies on bud rot disease}

\section{Survival of pathogen in diseased gardens}

\section{a) In crown}

Survival of Phytophthora propagules was observed in the axils of diseased and healthy palms. The extent of survival was found to be higher in diseased palms than the healthy palms. In endemic areas like Mandapam (Kasaragod Dt.), Josegiri (Kannur Dt.), Udyagiri and Kuttiadi (Kozhikode Dt.) where bud rot incidence was found to be increasing year after year, the survival percentage of Phytophthora propagules was very high. The wet samples which were collected from the axils of the leaves, readily yielded Phytophthora without additional moistening. This result showed the survival of the active inoculum in the wet organic matter. The dry samples yielded Phytophthora only after moistening with sterile distilled water and incubation at $24 \pm 1^{0} \mathrm{C}$ for $6-12$ days. Table-3 shows the survival rate of Phytophthora in bud rot affected coconut garden in the crown debris. Phytophthora infects the soft spear leaf of 
coconut and the close proximity of the spear leaf with leaf axils give a strong clue that the presence of inoculum in the leaf axils is a crucial factor in the initiation of infection in spear leaf. This also points towards the importance of crown cleaning for avoiding the disease incidence during monsoon. The inoculum present in the healthy trees can multiply during favourable season and can cause infection of the spear leaf. Phytophthora propagules were isolated from crown debris of dead trees even after one year. This shows the potential hazard exerted by the diseased trees as a source of inoculum in the subsequent season.

\section{b) In roots}

Phytophthora colonies were obtained in higher rate of success in isolation was obtained from 4 plots studied i.e. in Mandapam, Josegiri, Udayagiri and Kuttiadi where disease incidence was very high. Table-4 shows the survival percentage of Phytophthora in coconut roots collected from bud rot affected coconut gardens. Epiphytic survival of $P$. palmivora in the roots of both healthy and diseased coconut palms were reported for the first time by Harris et al. (1984). Thus this study yield evidence for the epiphytic survival of $P$. palmivora in coconut roots. Its association with coconut roots and survival in the roots can act as a source for the incitant of bud rot disease.

c) In soil

Propagules of Phytophthora were found to survive in the basins of healthy and diseased palms in bud rot affected gardens. Higher rate of success in isolation was obtained from 4 plots studied i.e. in mandapam, Josegiri, Udayagiri and Kuttiadi where disease incidence was very high. This shows that the environmental conditions in the endemic areas in northern Kerala are highly conducive for the rapid multiplication of the initial inoculum and to produce an epidemic. Table-5 shows the survival percentage of Phytophthora in soil of bud rot affected coconut gardens. Onesirosan (1971) reported that infectious propagules of Phytophthora is present in soil and can act as primary source of inoculum in the establishment of the disease.

\section{Trapping of Phytophthora propagules from rain water}

Differences due to places, disease vs healthy, and height are found to be significant for trapping of Phytophthora propagules from rain water. Mandapam was found to record significantly higher trapping than that compared to CPCRI samples. Rainwater from the diseased palms was found to record significantly higher trapping than that from the healthy. Rain water collected from the base of the crown recorded significantly higher trapping than both $15 \mathrm{~cm}$ and $35 \mathrm{~cm}$ (Table 6). At $35 \mathrm{~cm}$ the trapping was minimum. This shows that the inoculam present in the crown were transported as far as the tray at the base of the crown through rain water. Phytophthora propagules were isolated from the trays fitted above $15 \mathrm{~cm}$ from the ground. This may be due to the rain water splashing which has soil particles, and some times soil-borne Phytophthora propagules to the tray. It was also possible to trap Phytophthora from healthy trees, from the trays fitted to the base of the crown and also $15 \mathrm{~cm}$ above the ground. However, the percentage of isolation was high for the trays fitted to diseased palms compared to healthy palms. This indicates that rain water acts as a carrier for the infectious propagules and plays an important role in the spread of the disease (Thevenin, 1992; Brahmana et al., 1992).

\section{Survival of Phytophthora propagules in the slugs feces}

During the present study, Phytophthora propagules were found in the feces of slugs (Mariaella dussumieri) which were found among the crown debris of both diseased and healthy palms in endemic areas. However the frequency of occurrence was higher in the slugs collected from the diseased palms. Observations revealed that there was a higher \% of slugs in the infected crown than that of healthy. The rotting smell of the crown may be attracting these slugs. Sporangia, hyphal pieces and chlamydospores 
were found in the droppings of the slugs. From sporangia plenty of zoospores were released when treated with 'Petris' solution. These propagules were found viable and incite an infection when wound inoculation was done in the spear leaf. They produced characteristic lesions on the spear leaf. This suggests the possibility of these organisms acting as dispersal agents of Phytophthora propagules.

\section{Inter relationship between bud rot incidence and macro and micro climate}

The study of the relationship between temperature and macro, micro-humidity and disease incidence in Mandapam, Josegiri and Bowkanam revealed that, there is a high correlation between disease incidence and micro and macro-humidity in Mandapam and Josegiri. However, in the case of Bowkanam the correlation was not significant. Disease incidence was highly correlated with the macro and micro humidity of same month and also that of the previous two months. Table-7 a, b, and c shows the correlation matrices of the Mandapam, Josegiri and Bowkanam respectively.

\section{Forecasting equation for endemic plots of bud rot disease}

Regression equation $\left(y=a e^{b x}\right)$ was fitted for forecasting the number of diseased palms in each location in different months. The compound growth rate worked out showed that, it was higher for the locations 300-1350 M above MSL (Mandapam, Josegiri, Udayagiri, Kuttiadi) when compared to Bowkanam which is $150-300 \mathrm{M}$ above MSL (Table-8).

Efforts were made to develop a forecasting equation to forecast disease incidence in endemic areas (Mandapam and Josegiri) by using relative humidity level of the previous month. Out of the models studied, (same month, after 1, 2, 3,4,5 and 6 months) the one using both macro and micro humidities of previous month and another using the same variable of previous two months, gave the prediction equation with high $\mathrm{R}^{2}$ at Mandapam.
The forecasting equations for Mandapam plot are:

1. $\mathrm{Y}=(82.2)-2.764 \mathrm{RH}_{\mathrm{MACRO}}+2.065 \mathrm{H}_{\mathrm{MICRO}}$ For this the $\mathrm{R}^{2}=0.756$

Where ' $\mathrm{Y}$ ' is the disease incidence $(\%)$ of particular month

$\mathrm{RH}_{\text {MACRO }}$ is the average relative macro-humidity of the previous month

$\mathrm{RH}_{\text {MICRO }}$ is the average relative micro-humidity of the previous month

2. $\mathrm{Y}=(72.455)-4.315 \mathrm{RH}_{\mathrm{MACRO}}+3.699 \mathrm{RH}_{\mathrm{MICRO}}$ For this the $\left(\mathrm{R}^{2}=0.759\right)$

Where ' $\mathrm{Y}$ ' is the disease incidence (\%) of a particular month

$\mathrm{RH}_{\text {MACRO }}$ is the average relative macro-humidity of the previous 2 months

$\mathrm{RH}_{\text {MICRO }}$ is the average relative micro-humidity of the previous 2 months

The forecasting equations for Josegiri plot are:

1. $\mathrm{Y}=(36.5)-\mathrm{RH}_{\mathrm{MACRO}}+0.2578 \mathrm{RH}_{\mathrm{MICRO}}$

For this the $\left(\mathrm{R}^{2}=0.623\right)$

Where ' $\mathrm{Y}$ ' is the disease incidence (\%) of particular month

$\mathrm{RH}_{\text {MACRO }}$ is the average relative macro-humidity of the previous month

$\mathrm{RH}_{\text {MICRO }}$ is the average relative micro-humidity of the previous month

2. $\mathrm{Y}=(37.9)-0.2629 \mathrm{RH}_{\mathrm{MACRO}}+3.699 \mathrm{RH}_{\mathrm{MICRO}}$ For this the $\left(\mathrm{R}^{2}=0.634\right)$

Where ' $\mathrm{Y}$ ' is the disease incidence (\%) of a particular month

$\mathrm{RH}_{\text {MACRO }}$ is the average relative macro-humidity of the previous 2 months 
$\mathrm{RH}_{\text {MICRO }}$ is the average relative micro-humidity of the previous 2 months

The number of palms with bud rot Incidence in different months was estimated using regression equation $\mathrm{Y}=\mathrm{ae}^{\mathrm{bx}}$ (Table-9).

Forecasting disease incidence is very important for the management of the disease. So efforts were made to develop a forecasting equation to forecast disease incidence in endemic areas (Mandapam and Josegiri) by using relative humidity level of the previous months. Out of the models studied, (same month, previous 1, 2, 3,4,5 and 6 months) the one using both macro and micro - humidities of previous month and another using the same variable of previous two months gave the prediction equation with high $\mathrm{R}^{2}$ at Mandapam and Josegiri. The incubation period between the suitable micro climate and disease incidence is the time taken for fungus penetration followed by its development inside the coconut crown up to reaching the bud and the appearance of the first external symptom. This model has a distinct advantage that the onset of the disease can be predicted with in time using this equation. From Table-9 it is very clear that the difference between the predicted and actual disease incidence has been insignificant. Thus it is very clear that bud rot can be predicted with very reasonable accuracy based on the macro and micro climate. This is the first time a forecasting equation was developed for predicting bud rot disease in Kerala. This would help the farmers to take up prophylactic measures before the disease out break and there by to save the palms from the lethal disease.

\section{Conclusion}

Disease incidence was high in tracts where cooler temperatures coupled with very high relative humidity prevailed for extended periods in the coconut crown because of the high altitude of the place. Disease incidence in the hilly areas continued even after the cessation of the North East monsoon up to January. However, in the plains the disease incidence was recorded only up to September. The probable reason for this is due to prevalence of misty condition and cooler temperature that supported multiplication of the pathogen. Phytophthora propagules are surviving in the basins and axils of diseased and healthy palms even in the off season. Phytophthora propagules were isolated from crown debris of dead trees even after one year. This shows the potential hazard exerted by the diseased trees as a source of inoculum in the subsequent season. Phytophthora propagules were isolated from crown debris of dead trees even after one year. This shows the potential hazard exerted by the diseased trees as a source of inoculum in the subsequent season. Disease incidence in the endemic areas can be predicted with reasonable accuracy based on the temperature and humidity regimes of the locality (macro and micro temperature and humidity levels) at least one month in advance. This would help forewarn the farmers for taking plant protection measures to check bud rot incidence.

\section{References}

Anonymous, 1996. Severe bud rot of coconut at Kuttiady area in Kerala. Indian Express September 20, 1996.

Brahmana, J, Lubis, A. U. and DesmierDe Chenon, R. 1992. Evolution of coconut bud rot disease and control strategies (observation in Bangum, Purba and North Sumatra) Coconut Phytophthora Workshop Proceedings 26-30, Oct. 1992. Manado, Indonesia, Pp.33-37.

Butler, E.J. 1906. Some diseases of palms. Agric. J. India 1: 299-310.

Harris, D.C., Cardon, J.A., Justin, S.H.F.W. and Passey, A.J. 1984. Phytophthora palmivora on the cultured roots of coconut. Trans. Brit. Mycol. Soc.82 (2): 249-255.

Mangindaan, H., Thevenin, J.M., Knarie, S. and Motulo, H.F.J. 1992. The susceptibility of coconut varieties to Phytophthora in Indonesia: The effect of environmental factors. Coconut Phytophthora Workshop Proceedings. October 1992, Manado, Indonesia, pp. 39-46. 
Table 1. Bud rot incidence in certain districts of Kerala state recorded during the year 1999 - 2000

\begin{tabular}{|l|c|c|c|c|}
\hline \multicolumn{1}{|c|}{ Districts } & $\begin{array}{c}\text { Number of } \\
\text { plots surveyed }\end{array}$ & $\begin{array}{c}\text { Total number } \\
\text { of palms } \\
\text { observed }\end{array}$ & $\begin{array}{c}\text { Number of } \\
\text { palms with } \\
\text { bud rot }\end{array}$ & $\begin{array}{c}\text { \% of disease } \\
\text { incidence }\end{array}$ \\
\hline Kasaragod & 258 & 10136 & 438 & 4.32 \\
\hline Kannur & 215 & 13857 & 496 & 3.57 \\
\hline Calicut & 160 & 12125 & 428 & 3.52 \\
\hline Wynad & 98 & 1315 & 115 & 3.94 \\
\hline Thrissur & 138 & 2158 & 12 & 0.55 \\
\hline Malappuram & 129 & 1928 & 15 & 0.77 \\
\hline Palakkad & 132 & 2015 & 8 & 0.39 \\
\hline Ernakulam & 120 & 1156 & 6 & 0.51 \\
\hline
\end{tabular}

Table 2. Proportion of diseased palms in northern districts of Kerala

\begin{tabular}{|l|c|c|c|}
\hline Place & $\begin{array}{c}\text { Proportion of } \\
\text { diseased palms in } \\
\text { the hilly tracts }\end{array}$ & $\begin{array}{c}\text { Proportion of } \\
\text { diseased palms } \\
\text { in the } \\
\text { plains }\end{array}$ & Z value \\
\hline Kasaragod & 0.0699 & 0.0060 & $15.78^{* *}$ \\
\hline Calicut & 0.0644 & 0.0054 & $18.23^{* *}$ \\
\hline Kannur & 0.0763 & 0.0039 & $22.78^{* *}$ \\
\hline Pooled data & 0.0709 & 0.0049 & $33.00^{* *}$ \\
\hline
\end{tabular}

**Significant at $1 \%$

Table 3. Survival of Phytophthora in the crown of coconut palms

\begin{tabular}{|l|c|c|c|c|}
\hline \multirow{2}{*}{\multicolumn{1}{c|}{ Location }} & \multicolumn{2}{|c|}{ Healthy palms } & \multicolumn{2}{c|}{ Bud rot affected palms } \\
\cline { 2 - 5 } & $\begin{array}{c}\text { Total number } \\
\text { of samples } \\
\text { observed }\end{array}$ & $\begin{array}{c}\text { \% of isolates } \\
\text { obtained }\end{array}$ & $\begin{array}{c}\text { Total } \\
\text { number of } \\
\text { samples } \\
\text { observed }\end{array}$ & $\begin{array}{c}\text { \% of isolates } \\
\text { obtained }\end{array}$ \\
\hline CPCRI Kasaragod & 50 & $18(9)^{*}$ & 5 & $40(2)$ \\
\hline CPCRI Seed farm Kidu & 50 & $16(8)$ & 10 & $80(8)$ \\
\hline Mandapam & 50 & $42(21)$ & 20 & $90(18)$ \\
\hline Josegiri & 50 & $38(19)$ & 20 & $95(19)$ \\
\hline Udayagiri & 50 & $30(15)$ & 20 & $90(18)$ \\
\hline Kuttiadi & 50 & $24(12)$ & 20 & $80(16)$ \\
\hline
\end{tabular}


Table 4. Survival of Phytophthora in the roots

\begin{tabular}{|l|c|c|c|c|}
\hline \multirow{2}{*}{ Location } & \multicolumn{2}{|c|}{ Healthy palms } & \multicolumn{2}{c|}{ Bud rot affected palms } \\
\cline { 2 - 5 } & $\begin{array}{c}\text { Total number } \\
\text { of samples } \\
\text { observed }\end{array}$ & $\begin{array}{c}\text { \% of isolates } \\
\text { obtained }\end{array}$ & $\begin{array}{c}\text { Total number } \\
\text { of samples } \\
\text { observed }\end{array}$ & $\begin{array}{c}\% \text { of isolates } \\
\text { obtained }\end{array}$ \\
\hline CPCRI Kasaragod & 20 & $0(0)$ & 5 & $0(0)$ \\
\hline CPCRI Seed farm Kidu & 20 & $0(0)$ & 10 & $10(0)$ \\
\hline Mandapam & 20 & $15(3)$ & 20 & $25(5)$ \\
\hline Josegiri & 20 & $20(4)$ & 20 & $40(8)$ \\
\hline Udayagiri & 20 & $15(3)$ & 20 & $30(6)$ \\
\hline Kuttiadi & 20 & $15(3)$ & 20 & $30(6)$ \\
\hline
\end{tabular}

Table 5. Survival of Phytophthora in the soil

\begin{tabular}{|l|c|c|c|c|}
\hline \multirow{2}{*}{ Location } & \multicolumn{2}{|c|}{ Healthy palms } & \multicolumn{2}{c|}{ Bud rot affected palms } \\
\cline { 2 - 5 } & $\begin{array}{c}\text { Total number } \\
\text { of samples } \\
\text { observed }\end{array}$ & $\begin{array}{c}\text { \% of isolates } \\
\text { obtained }\end{array}$ & $\begin{array}{c}\text { Total number } \\
\text { of samples } \\
\text { observed }\end{array}$ & $\begin{array}{c}\% \text { of isolates } \\
\text { obtained }\end{array}$ \\
\hline CPCRI Kasaragod & 20 & $-(0)$ & 5 & $20(1)$ \\
\hline CPCRI Seed farm Kidu & 20 & $-(0)$ & 10 & $20(2)$ \\
\hline Mandapam & 20 & $15(3)$ & 20 & $45(9)$ \\
\hline Josegiri & 20 & $15(3)$ & 20 & $50(10)$ \\
\hline Udayagiri & 20 & $20(4)$ & 20 & $55(11)$ \\
\hline Kuttiadi & 20 & $15(3)$ & 20 & $45(9)$ \\
\hline
\end{tabular}

* Figures in parentheses are number of isolations obtained

Table 6. Trapping of Phytophthora propagules from rain water

\begin{tabular}{|c|c|c|c|c|c|c|}
\hline \multirow{2}{*}{ Location } & \multicolumn{6}{|c|}{ \% trapping of Phytophthora propagules from rain water } \\
\cline { 2 - 7 } & \multicolumn{3}{|c|}{ Diseased } & \multicolumn{3}{c|}{ Healthy } \\
\hline \multirow{3}{*}{ Mandapam } & $15 \mathrm{~cm}$ & $35 \mathrm{~cm}$ & $\begin{array}{c}\text { Base of the } \\
\text { crown }\end{array}$ & $15 \mathrm{~cm}$ & $35 \mathrm{~cm}$ & $\begin{array}{c}\text { Base of the } \\
\text { crown }\end{array}$ \\
\cline { 2 - 7 } & $\begin{array}{c}11.057 \\
(6.00)^{*}\end{array}$ & $\begin{array}{c}3.68 \\
(2.00)\end{array}$ & $\begin{array}{c}25.104 \\
(22.00)\end{array}$ & $\begin{array}{c}3.68 \\
(2)\end{array}$ & $\begin{array}{c}0.00 \\
(0.00)\end{array}$ & $\begin{array}{c}7.37 \\
(4.00)\end{array}$ \\
\hline \multirow{2}{*}{ CPCRI } & $\begin{array}{c}3.686 \\
(2.00)\end{array}$ & $\begin{array}{c}0.00 \\
(0.00)\end{array}$ & $\begin{array}{c}5.31 \\
(4.00)\end{array}$ & $\begin{array}{c}0.00 \\
(0.00)\end{array}$ & $\begin{array}{c}0.00 \\
(0.00)\end{array}$ & $\begin{array}{c}3.68 \\
(2.00)\end{array}$ \\
\hline
\end{tabular}

(Transformation used: $\sin ^{-1} \mathrm{vp}$, where 'p' is the proportion of Phytopthora propagules trapped)

*Figures in parentheses are actual percentages
Gen. Mean $=5.29$
C.D. $(\mathrm{P}=0.05)$ for places $=4.34$
SE/Plot $=8.37$
C.D. $(\mathrm{P}=0.05)$ for diseased $\mathrm{x}$ healthy $=4.34$
C.V. $(\%)=158.01$
C.D. $(\mathrm{P}=0.05)$ for height $=5.32$ 
Table 7. Relationship between bud rot incidence and macro and micro climate

a) Correlation Matrix - Mandapam

\begin{tabular}{|c|c|c|c|c|}
\hline \multirow{2}{*}{ Bud rot incidence in } & \multicolumn{2}{|c|}{ Temperature } & \multicolumn{2}{c|}{ Relative humidity } \\
\cline { 2 - 5 } & Macro & Micro & Macro & Micro \\
\hline Same month & 0.320 & 0.453 & $-0.802 . \wedge$ & $-0.780 . \$$ \\
\hline After 1 months & 0.259 & 0.375 & $-0.820 \wedge$ & $-0.780 \$$ \\
\hline After 2 months & 0.174 & 0.171 & $-0.707 \$$ & -0.642 \\
\hline After 3 months & 0.088 & 0.048 & -0.602 & -0.53 \\
\hline After 4 months & 0.149 & 0.0076 & -0.474 & -0.417 \\
\hline After 5 months & 0.104 & -0.076 & -0.388 & -0.32 \\
\hline After 6 months & -0.20 & -0.28 & -0.06 & -0.007 \\
\hline
\end{tabular}

b) Correlation Matrix - Josegiri

\begin{tabular}{|c|c|c|c|c|}
\hline \multirow{2}{*}{ Bud rot incidence in } & \multicolumn{2}{|c|}{ Temperature } & \multicolumn{2}{c|}{ Relative humidity } \\
\cline { 2 - 5 } & Macro & Micro & Macro & Micro \\
\hline Same month & 0.488 & 0.23 & $-0.835 \wedge$ & $-0.84 \wedge$ \\
\hline After 1 month & 0.43. & 0.149 & $-0.78 \$$ & $-0.79 \$$ \\
\hline After 2 months & 0.24 & -0.02 & -0.65 & -0.664 \\
\hline After 3 months & 0.10 & -0.18 & -0.46 & -0.48 \\
\hline After 4 months & 0.23 & -0.09 & -0.47 & -0.48 \\
\hline After 5 months & 0.20 & -0.129 & -0.369 & -0.38 \\
\hline After 6 months & -0.01 & -0.23 & -0.150 & -0.18 \\
\hline
\end{tabular}

c) Correlation Matrix - Bowkanam

\begin{tabular}{|c|c|c|c|c|}
\hline \multirow{2}{*}{ Bud rot incidence in } & \multicolumn{2}{|c|}{ Temperature } & \multicolumn{2}{c|}{ Relative humidity } \\
\cline { 2 - 5 } & Macro & Micro & Macro & Micro \\
\hline Same month & $0.687 \$$ & $0.683 \$$ & $-0.756 \$$ & $-0.752 \$$ \\
\hline After 1 month & 0.44 & 0.455 & -0.58 & $-0.57 \$$ \\
\hline After 2 months & 0.069 & 0.025 & -0.355 & -0.355 \\
\hline After 3 months & 0.032 & -0.61 & 0.00 & -0.01 \\
\hline After 4 months & 0.00 & 0.00 & 0.00 & 0.00 \\
\hline After 5 months & 0.00 & 0.00 & 0.00 & 0.00 \\
\hline After 6 months & 0.00 & 0.00 & 0.00 & 0.00 \\
\hline
\end{tabular}

$\$=$ significant at $5 \%$ level

$\wedge=$ significant at $1 \%$ level 
Table 8. Regression equation with CGR in different bud rot affected locations

\begin{tabular}{|l|c|c|c|c|l|}
\hline \multicolumn{1}{|c|}{ Location } & A & b & Se (b) & \multicolumn{1}{|c|}{$\mathrm{R}^{2}$} & \multicolumn{1}{c|}{ CGR } \\
\hline $\begin{array}{l}\text { Mandapam } \\
\text { (300-1350M above MSL) }\end{array}$ & 3.9110 & 0.0691 & 0.008428 & 0.9180 & $7.15^{*}$ \\
\hline $\begin{array}{l}\text { Josegiri } \\
(300-1350 \mathrm{M} \text { above MSL) }\end{array}$ & 3.2783 & 0.0783 & 0.008475 & 0.9344 & $8.15^{*}$ \\
\hline $\begin{array}{l}\text { Udayagiri } \\
(300-1350 \mathrm{M} \text { above MSL) }\end{array}$ & 3.1693 & 0.0609 & 0.006790 & 0.9306 & $6.28^{*}$ \\
\hline $\begin{array}{l}\text { Kuttiadi } \\
\text { (300-1350M above MSL) }\end{array}$ & 3.0220 & 0.0563 & 0.008685 & 0.9355 & $5.80^{*}$ \\
\hline $\begin{array}{l}\text { Bowkanam } \\
(150-300 \mathrm{M} \text { above MSL) }\end{array}$ & 1.3863 & 0.0398 & 0.010288 & 0.7143 & $4.07^{*}$ \\
\hline
\end{tabular}

*Significant at $5 \%$

Table 9. Estimated value for bud rot incidence in different locations by regression equation $Y=a e^{b x}$

\begin{tabular}{|c|c|c|c|c|c|c|c|}
\hline \multirow{2}{*}{ Location } & \multicolumn{7}{|c|}{ Estimated value for bud rot disease in 1999 } \\
\cline { 2 - 8 } & July & August & September & October & November & December & January \\
\hline $\begin{array}{c}\text { Mandapam } \\
\text { (300-1350M } \\
\text { above MSL) }\end{array}$ & $\begin{array}{c}57.35 \\
(55.00)^{*}\end{array}$ & $\begin{array}{c}65.45 \\
(58.00)\end{array}$ & $\begin{array}{c}65.85 \\
(62)\end{array}$ & $\begin{array}{c}70.56 \\
(68.00)\end{array}$ & $\begin{array}{c}75.61 \\
(73.00)\end{array}$ & $\begin{array}{c}81.02 \\
(79.00)\end{array}$ & $\begin{array}{c}86.81 \\
(84.00)\end{array}$ \\
\hline $\begin{array}{c}\text { Josegiri } \\
(300-1350 \mathrm{M} \\
\text { above MSL) }\end{array}$ & $\begin{array}{c}31.02 \\
(26.00)\end{array}$ & $\begin{array}{c}33.55 \\
(28.00)\end{array}$ & $\begin{array}{c}36.288 \\
(35.00)\end{array}$ & $\begin{array}{c}39.244 \\
(38.00)\end{array}$ & $\begin{array}{c}42.44 \\
(39.00)\end{array}$ & $\begin{array}{c}45.89 \\
(42.00)\end{array}$ & $\begin{array}{c}49.63 \\
(46.00)\end{array}$ \\
\hline $\begin{array}{c}\text { Udayagiri } \\
(300-1350 \mathrm{M}\end{array}$ & 26.87 & $\begin{array}{c}28.55 \\
(25.00)\end{array}$ & $\begin{array}{c}30.35 \\
(28.00)\end{array}$ & $\begin{array}{c}32.25 \\
(31.00)\end{array}$ & $\begin{array}{c}34.28 \\
(34.00)\end{array}$ & $\begin{array}{c}36.437 \\
(35.00)\end{array}$ & $\begin{array}{c}38.72 \\
(36.00)\end{array}$ \\
\hline $\begin{array}{c}\text { Kuttiadi } \\
\text { (300-1350M } \\
\text { above MSL) }\end{array}$ & $\begin{array}{c}22.97 \\
(22.00)\end{array}$ & $\begin{array}{c}24.31 \\
(22.00)\end{array}$ & $\begin{array}{c}25.718 \\
(23.00)\end{array}$ & $\begin{array}{c}27.2 \\
(26.00)\end{array}$ & $\begin{array}{c}28.78 \\
(27.00)\end{array}$ & $\begin{array}{c}30.45 \\
(30.00)\end{array}$ & $\begin{array}{c}32.21 \\
(31.00)\end{array}$ \\
\hline $\begin{array}{c}\text { Bowkanam } \\
(150-300 \mathrm{M} \\
\text { above MSL) }\end{array}$ & $\begin{array}{c}4.33 \\
(4.00)\end{array}$ & $\begin{array}{c}4.50 \\
(5.00)\end{array}$ & $\begin{array}{c}4.69 \\
(6.00)\end{array}$ & $\begin{array}{c}4.88 \\
(6.00)\end{array}$ & $\begin{array}{c}5.07 \\
(6.00)\end{array}$ & $\begin{array}{c}5.28 \\
(6.00)\end{array}$ & $\begin{array}{c}5.49 \\
(6.00)\end{array}$ \\
\hline
\end{tabular}

* Figures in parentheses are observed values 
Menon, K.P.V. and Pandalai, K.M. 1958. The Coconut Palm - A Monograph. Indian Central Coconut Committee, Ernakulam, India, 384 pp.

Onesirosan, P. 1971. The survival of Phytophthora palmivora in cacao plantation during the dry season. Phytopathology 61: 975-977.

Pohe, J. 1992. Factors involved in the development of nut fall due to Phytophthora in Cote-d-Ivoire. Coconut Phytophthora Workshop Proceedings, 2630, Oct. 1992. Manado, Indonesia, pp. $47-$ 50.

Radha, K. and Joseph, T. 1974. Investigations on the bud rot disease (Phytophthora palmivora) of coconut. Final Report $P L$ 480 Scheme. CPCRI, Kayangulam, India, 32pp.
Steer, E.D. 1992. Coconut bud rot disease in Jamaica. Coconut Phytophthora Workshop Proceedings, 26-30, Oct. 1992. Manado, Indonesia, pp. 51-56.

Thevenin, J.M, Motulo, H.F.J, Kharie, S, Mangindann, H.F. and Warokkha, J.S. 1992. Epidemiological studies on Phytophthora diseases of coconut in north Sulawezi province, Indonesia. Coconut Phytophthora Workshop Proceedings, 2630, Oct. 1992. Manado, Indonesia, pp. 2125.

Thevenin, J.M. 1992. Coconut Phytophthora diseases in Indonesia: etiological aspects. Coconut Phytophthora Workshop Proceedings, 26-30, Oct. 1992. Manado, Indonesia, pp. 27-31.

Tucker, C.M. 1926. Phytophthora bud-rot of coconut palms in Puerto Rico. J. Agric. Res. 32: 471-498. 